\title{
Philosophical Expositions of Leadership and Human Values in Catholic Social Teachings: Resolving Nigeria’s Leadership Deficit and Underdevelopment
}

\author{
Ani Casimir ${ }^{1}$, Onah Nkechinyere ${ }^{2}$, Rev.Canon Collins Ugwu ${ }^{2}$, Maudline Okpara ${ }^{3}$ \\ ${ }^{1}$ Institute of African Studies, Department of Philosophy, University of Nigeria, Nsukka, Nigeria \\ ${ }^{2}$ Department of Religion and Cultural Studies, University of Nigeria, Nsukka, Nigeria \\ ${ }^{3}$ School of General Studies, University of Nigeria, Nsukka, Nigeria \\ Email: cepperngo@yahoo.com,nkglo06@yahoo.com,collins.ugwu@unn.edu.ng, maudlineokpara@gmail.com
}

Received April $3^{\text {rd }}$, 2013; revised May $3^{\text {rd }}$, 2013; accepted May $10^{\text {th }}, 2013$

Copyright (c) 2013 Ani Casimir et al. This is an open access article distributed under the Creative Commons Attribution License, which permits unrestricted use, distribution, and reproduction in any medium, provided the original work is properly cited.

\begin{abstract}
In spite of Nigeria's vaunted claims to leadership of the African continent and the entire black race, the country tragically suffers from an enduring self leadership deficit that has had a negative impact on its development. The masses of the people had been alienated by the ruling class from governance and a lot of ethnic groups had been marginalized and excluded from participating in democratic power. This has manifested in different typologies of conflicts and systemic failure which had served to undermine development planning since the country's independence. This paper explores some existing but unexplored linkages, immediate and mediate, between Catholic Social Teachings and some particular school of leadership, human values and conflict resolution frameworks, which could, in the future, generate sustainable solutions to the problems of the Nigerian leadership and development challenge in the twenty first century. After a brief survey of community participatory leadership and interactive leadership theories under the framework of transformational leadership concept, we will look at the critical recurring components in community participatory leadership, the five human values, and conflict resolution theories as contained in the Catholic Social Teachings. Our examination of Catholic Social Teachings will be drawn primarily from the social encyclicals beginning with Pope Leo XIII's Rerum nova rum and continuing through the social encyclicals of Pope John Paul II. These critical recurring components we have noted include: 1) a transforming vision; 2) community participation in decision-making; 3) power; 4) affirmation of others' human values such as need for truth, integrity, love, peace, non-violence, worth, or dignity; and 5) conflict resolution. The paper argues effectively that human value concepts are reflected in both the frameworks of transformative leadership, a fundamental content of the catholic social teachings, seen as a veritable answer to the problems of leadership in Nigeria. The article will use analytical and dialectical expositions to explore these theoretical linkages and draw enduring lessons for Nigeria.
\end{abstract}

Keywords: Philosophy; Human Values; Leadership; Transformation; Interactive; Participation and Catholic Social Teachings; Underdevelopment

\section{Background to the Study-Nigeria's Leadership Failure and Its Negative Impact on Development}

Professor Chinua Achebe (1993), in his epochal work entitled "The Problem with Nigeria", singled out the leadership challenge as a basic and fundamental problems to every other problem facing the country. In another classical and well researched work of history, "Once there was a country", that portrayed the root causes of the Nigerian Biafra war (1967-1970), Professor Achebe (2012) narrowed down the leadership problem of Nigeria to a visionless, selfish and corrupt ruling elite who had destroyed the basic underlying roots of the country's unity and peace by pursuing power without a development agenda for the country. This leadership adventure since independence has gradually pushed Nigeria to the precipice of a failing state. Though the general analysis and scholarship have tended to point accusing fingers at both failures of leadership and follower ship (Oyebode, 2012: p. 68), it is the underperforming leadership thrust upon the country since independence that has failed to steer the ship of the Nigerian state and bequeath the dividends of development and democracy on the people. Nigeria's elites have always believed in the concept of leadership that authority comes from force, deception and corrupt electoral process that purchases power from the people by guile. During the military regimes that destroyed the country's democratic culture, power is gotten by the soldiers through the barrels of the gun. The idea that power comes from God, a basic fundamental of catholic social teaching, is indeed foreign to such power mongers who struggle for leadership positions with out any pro-people or progressive agenda that includes considerations for people's welfare. It is time for paradigm shift in this thing and mindset to a leadership concept that emphasizes humane values as embodied in the catholic social teachings and 
reflected in both transformation al and community participatory leadership. This is the leadership concept that solves conflicts and brings about sustainable development to nations, but has been missing in Nigeria.

Good governance has been a missing element in the developmental process of Nigeria; but this is precisely because of the absence of good leadership as defined in the context of both catholic social teachings and global good governance index. Good governance has a lot to do with leadership since leadership drives the levers of governance in using authority to take decisions in a democratic manner and context a society, government, community or countries are managed to achieve sustainable development. Central to this concept is that while the leadership has the final say in decision making in governance and public policies, other players such citizens, civil society and members of the organized private sector must contribute and participate in taking that decisions in a manner that portrays that people have choices. Nigeria's leadership and governance structures do not allow for community or civil society participation in public policy. As a result governments in Nigeria functions to serve the interests of only the ruling elite to the exclusion of the people of Nigeria.

According to White (1994), Governance in countries such as in Nigeria is considered to be askewed because of the poor character of leadership they have had since independence and this poor specie of leadership has brought about weak elements of governance such as lack of participation of people in governance. Participation as aspect of good governance and leadership is fundamental as it enables ordinary citizens, especially the marginalized and the poor in the country to influence decision-making. In the 1990s, discourse on participation originally focused on community or social participation of "beneficiaries" in development projects. In furtherance of this philosophical idea, the World Bank Learning Group (1995) defined participation as a "process through which stakeholders influence and share control over development initiatives and the decisions and resources which affect them". Since then, there has been an increasing emphasis on engaging people as citizens in activities that traditionally formed part of the state sphere. It is argued that such increased political participation will improve the efficiency of public services, will make local government more accountable, and will deepen democracy-complementing representative forms with more participatory forms of democracy. Lack of participation of people in governance brings about a disconnect that has created a vicious cycle of conflicts and poverty in Nigeria. Oyebode (2012: p. 67) depicts the negative impact of this disconnect between the leadership, governance and the Nigerian people with the following observations:

A wise leadership cannot afford to be too far ahead of the people or alienate them in the developmental process. Such a situation much sooner than later becomes a recipe for failure as a people not carried along by the leadership loses interests and becomes disenchanted by the otherwise lofty programs and policies adumbrated by the leadership. Disconnect gives rise to lethargy and lethargy generates docility and inaction from the intended beneficiaries of the grandiose ideas articulated by the leadership. Accordingly it is a matter of utmost necessity for the leadership to strike a very good balance between its proposals and yearnings of the generality of the people if it wishes to succeed in the actualization of its vision. Accountability, transparency and commitment to the tenets of democracy and good governance constitute the leitmotif to responsible leadership.

There is no doubt that Nigeria suffers a from a failure of leadership, and this consistent failure has created a disconnect between the people and ruling elite in the country since independence; it has led to a vicious cycle of poverty, corruption, underdevelopment, misplaced priorities, conspicuous consumption lifestyles, widening gap between the leadership and the followership. The leadership in Nigeria has consistently failed to reflect personal example in living a human lifestyle that would depict them as embodiments of the values we have seen in exemplary ethical models. It is germane to evaluate such models of leadership and their participatory systems which reflect the values inherent in the catholic social teachings.

\section{Introduction to Community Participatory and Leadership Theories}

Community participatory leadership as a concept flows from the understanding that leadership in a society derives from the people and it is for the benefit of the people. Effective leaders have followers who participate in leadership activities and contribute dynamically in decision making for policy formulation, implementation and monitoring. According to Kanu (2011: p. 23) this collegiate concept of leadership is what drives the framework of workable democracies and give them a popular content. Community participatory leadership is also akin to the concept of interactive leadership model. According to Mary Elsebernd (2003) "interactive leadership has its roots in participative management approaches, in transformational leadership theories, and in situation-contingent models of leadership. Its links to participative management approaches are quite clear in Judy Rosener's (1990) description of interactive leadership. Rosener's description notes the following characteristics of interactive leadership: 1) encouragement of participation in all aspects of work; 2) wide-spread sharing of information and power; 3) efforts to enhance self-worth of employees; and 4) energizing employees for the task.

In the same article, Rosener also links interactive leadership to the transformational leadership theories of James McGregor Burns (1978) and Bernard Bass (1985) and Victor Kanu's community leadership participatory model (2011). In that framework all the aforementioned authors portray and conceive a transformational leader as one who is able to shift the needs, self-interest, values, and beliefs of individual followers into the interest or vision of the group. According to Kanu (Cf. Tichy \& Devanna, 1986; Nanus, 1992; Nygren \& Ukeritis, 1993; Rhodes, 1993). According to Mary Elsebernd transformational leaders exhibit personal charisma, self-confidence, dominance and a conviction that their vision is morally right. Avolio, Waldman, \& Yammarino (1991) talk about the characteristics of the transformational leader mnemonically: individualized attention, intellectual stimulation, inspirational motivation and idealized influence. Some transformational leadership theories emphasize change and transformation as the role of the leader (Nanus, 1992; Tichy \& Devanana, 1986).

\section{Leadership, Interaction, and the Followership}

Leadership becomes transformational through participatory frameworks such as community consultation and interaction. 
The interests and goals of the community become the fulcrum of good leadership. According to Kanu (2011): leadership becomes transformational when it is becomes a moral value framework of constant interaction, link and consultation between the leadership and the followership with the common interests and goals of the society in view. Tranformational leadership is the same as interactive leadership since part of its essential definition is constant interaction between the leaders and the followers. The Wikipedia defines transformational leadership as follows:

Transformational leadership enhances the motivation, morale and performance of followers through a variety of mechanisms. These include connecting the follower's sense of identity and self to the mission and the collective identity of the organization; being a role model for followers that inspires them; challenging followers to take greater ownership for their work, and understanding the strengths and weaknesses of followers, so the leader can align followers with tasks that optimize their performance. Anne Staham (1987), in turn, links interactive leadership to social structural theories of symbolic interactionism (Stryker, 1980) which hold that social structure and behavioral interaction mutually influence each other. Staham recognizes earlier, foundational contributions of both Fiedler (1967) and House (1971) in situation-contingent leadership theories.

Given these roots, Klenke (1996) speaks of a "complex pattern of interactions among leaders, followers, and situations", all of which are played out within a broader framework of gender role expectations. For Klenke context, culture, gender, and leadership/followership as well as the tasks, the specific organizational structures and personalities are all components in the social construction of leadership. All of these components mutually interact in the practice and the resultant theories of leadership.

Klenke dares to sketch some properties of the vision and some values of this interactive leadership model:

Interactive leadership entails the formulation and communication of a shared vision of the future which is capable of creating common ground out of diversity and which offers creative response to change. The exact content of the vision is unclear, although terms like "higher levels of moral development”, "noble ideals”, and the embrace of all humanity are mentioned in reference to the vision. Nanus (1992) maintains that transforming visions must 1) be appropriate for the future of the organization; 2) provide a clear purpose or direction; 3) inspire and urge commitment; 4) be articulated and communicated; and 5) be ambitious. The interactive leader typically holds the values of participation in decision-making, empowerment of followers, mutuality and reciprocity in leader-follower relations, and consensus-building.

This listing of values finds resonance in other interactive as well as transformational leadership theories. For example, Rosener (1990) mentions participation, sharing power and information, enhancing others' self-worth, and energizing others for the interest and goals of the group. Helgersen (1990) includes principles of caring, conscious letting go of hierarchy by attending to the web-like relationships, information sharing, and collaborative negotiation. Haines (1994) calls for the ability to use power wisely, skills in conflict resolution and participatory decision-making. Nygren and Ukeritis (1993) note the following characteristics in outstanding leaders of religious congregations: understanding and use of power as access to available resources, consensus-building, affirmation of others' worth, shared power and information.

\section{Background and Development of Concept}

James MacGregor Burns (1978) first introduced the concept of transforming leadership in his descriptive research on political leaders, but this term is now used globally as a good conceptual framework for good leadership. According to Burns, transforming leadership is a process in which "leaders and followers help each other to advance to a higher level of morale and motivation”. The concept of transformational leadership which was initially introduced by leadership expert and presidential biographer opines that "through the strength of their vision and personality, transformational leaders are able to inspire followers to change expectations, perceptions and motivations to work towards common goals". He established two concepts: "transforming leadership" and "transactional leadership”. According to Burns, the transforming approach creates significant change in the life of people and organizations. It redesigns perceptions and values, and changes expectations and aspirations of employees. Unlike in the transactional approach, it is not based on a "give and take" relationship, but on the leader's personality, traits and ability to make a change through example, articulation of an energizing vision and challenging goals. Transforming leaders are idealized in the sense that they are a moral exemplar of working towards the benefit of the team, organization and/or community. One could say that tranformational leaders work with human values to change backsliding and retrogressive community habits through participatory change management. The problems identified in African governance have been variously traced to a leadership style and structure that is exclusive of community participation.

Later, researcher Bernard M. Bass (1985) expanded upon Burns original ideas to develop what is today referred to as Bass' Transformational Leadership Theory. According to Bass, transformational leadership can be defined based on the impact that it has on followers. Transformational leaders, Bass suggested, garner trust, respect and admiration from their followers. Bernard M. Bass (1985), extended the work of Burns by using the term "transformational" instead of "transforming leadership"; explained how transformational leadership could be measured, as well as how it impacts follower motivation and performance. As noted by Bass, B. M. (1985) the success of a leader could be adequately measured by the attitude of his followers towards his leadership style:

The extent to which a leader is transformational, is measured first, in terms of his influence on the followers. The followers of such a leader feel trust, admiration, loyalty and respect for the leader and because of the qualities of the transformational leader are willing to work harder than originally expected. These outcomes occur because the transformational leader offers followers something more than just working for self gain; they provide followers with an inspiring mission and vision and give them an identity. The leader transforms and motivates followers through his or her idealized influence (earlier referred to 
as charisma), intellectual stimulation and individual consideration. In addition, this leader encourages followers to come up with new and unique ways to challenge the status quo and to alter the environment to support being successful.

Bass (2008) suggested that leadership can simultaneously display both transformational and transactional leadership.and came out with his much awaited work-The Bass Handbook of Leadership: Theory, Research, and Managerial Applications, which recognises four elements of transformational leadership which define the full range of good leadership should drive good governance:

Individualized Consideration: Transformational leadership also involves offering support and encouragement to individual followers. In order to foster supportive relationships, transformational leaders keep lines of communication open so that followers feel free to share ideas and so that leaders can offer direct recognition of each followers unique contributions. In other words, the degree to which the leader attends to each follower's needs, acts as a mentor or coach to the follower and listens to the follower's concerns and needs. The leader gives empathy and support, keeps communication open and places challenges before the followers. This also encompasses the need for respect and celebrates the individual contribution that each follower can make to the team. The followers have a will and aspirations for self development and have intrinsic motivation for their tasks.

Intellectual Stimulation: Transformational leaders not only challenge the status quo; they also encourage creativity among followers. The leader encourages followers to explore new ways of doing things and new opportunities to learn. This is to say that the degree to which the leader challenges assumptions, takes risks and solicits followers' ideas. Leaders with this style stimulate and encourage creativity in their followers. They nurture and develop people who think independently. For such a leader, learning is a value and unexpected situations are seen as opportunities to learn. The followers ask questions, think deeply about things and figure out better ways to execute their tasks.

\section{Inspirational Motivation-Idealized Influence}

Transformational leaders have a clear vision that they are able to articulate to followers. These leaders are also able to help followers experience the same passion and motivation to fulfill these goals. In other words, the degree to which the leader articulates a vision that is appealing and inspiring to followers. Leaders with inspirational motivetion challenge followers with high standards, communicate optimism about future goals, and provide meaning for the task at hand. Followers need to have a strong sense of purpose if they are to be motivated to act. Purpose and meaning provide the energy that drives a group forward. The visionary aspects of leadership are supported by communication skills that make the vision understandable, precise, powerful and engaging. The followers are willing to invest more effort in their tasks, they are encouraged and optimistic about the future and believe in their abili- ties.

\section{Idealized Influence}

The transformational leaders serve as a role model for followers. Because followers trust and respect the leader, they emulate the leader and internalize his or her ideals. Provides a role model for high ethical behavior, instills pride, gains respect and trust. Bass also suggested that there were four different components of transformational leadership.

It is obvious that transformational leadership is all about changing minds and persuasions through the dynamics of community participation and constant interaction with between the leadership and the follower ship. As a development tool, transformational leadership has spread already in all sectors of western societies, but it is unfortunately crawling into the halls of community state and national governance frameworks in Africa. Even Faith-based, community and Civil Society Organizations in Africa are taking the lead in introducing the concept and strategy of transformational leadership as an example and model in their management systems.

\section{Global Assumptions about Transformational Leadership and Human Values}

Fundamentally, the transformational leader seeks to put into place an inclusive governance system that allows people, communities and other segments of organizations to participate and contribute to governance. However, his basic work as a leader is to transform: transform himself and the people through inspiring leadership programs. The implications of this basic postulate is that People will follow a person who inspires them; a person with vision and passion can achieve great things and that, finally, the way to get things done is by injecting vision, enthusiasm and energy into a leader's programs and strategies. According to the Mahavyaka (Gibbels, 2004) a good leader is only one who can transform others through his leadership; he must first transform himself before he can transform others. The concept of human values has been enshrined into the halls of creative leadership through the Sathya Sai Education in $\mathrm{Hu}-$ man Values (SSEHV) and the concept of sacrificing, selfless and transformational character it injects into human beings who observe and practice the five human values which define human divinity and dignity. According to Sathya Sai education in human values, "the purpose of education is not just for gathering information but for the transformation of the human being from the animal to the divine so that he can manifest civilized, refined and noble human qualities”. Human values define man's dignity, integrity and worth that enable and motivate him to manifest truth, peace, right conduct, non-violence and love as contents of his relationship to others. In other words, human values transform and transmute man from the beastly to the divine making it possible for man to live in tolerance and cooperative interaction with his fellows. According to Kanu (2011), when human values are practiced, human rights are respected and the leadership tenor becomes transformational and development oriented. There are key assumptions which the human values inject into the concept and practice of transformational leadership. They are style, developing and selling the vision of change, seeking the way forward, upfront charge for change, and dialoguing. These value inputs need to be elaborated be- 
low:

\section{Style}

A leader gets style simply because working for a Transformational Leader can be a wonderful and uplifting experience both for the leader and the led. They put passion and energy into everything. They care about you and want you to succeed.

\section{Developing the Vision}

Transformational Leadership starts with the development of a vision, a view of the future that will excite and convert potential followers. This vision may be developed by the leader, by the senior team or may emerge from a broad series of discussions. The important factor is the leader buys into it, hook, line and sinker.

\section{Selling the Vision}

The next step, which in fact never stops, is to constantly sell the vision. This takes energy and commitment, as few people will immediately buy into a radical vision, and some will join the show much more slowly than others. The Transformational Leader thus takes every opportunity and will use whatever works to convince others to climb

\section{Finding the Way Forwards}

In parallel with the selling activity is seeking the way forward. Some Transformational Leaders know the way, and simply want others to follow them. Others do not have a ready strategy, but will happily lead the exploration of possible routes to the promised land. The route forwards may not be obvious and may not be plotted in details, but with a clear vision, the direction will always be known. Thus finding the way forward can be an ongoing process of course correction, and the Transformational Leader will accept that there will be failures and blind canyons along the way. As long as they feel progress is being made, they will be happy.

\section{Upfront Charge for Change}

The final stage is to remain up-front and central during the action. Transformational Leaders are always visible and will stand up to be counted rather than hide behind their troops. They show by their attitudes and actions how everyone else should behave. They also make continued efforts to motivate and rally their followers, constantly doing the rounds, listening, soothing and enthusing. It is their unswerving commitment as much as anything else that keeps people going, particularly through the darker times when some may question whether the vision can ever be achieved. If the people do not believe that they can succeed, then their efforts will flag. The Transformational Leader seeks to infect and reinfect their followers with a high level of commitment to the vision.

\section{Discussion and Dialogue with the People}

As the Transformational Leader seeks to transform the organization and the community, there is also a tacit promise to followers that they also will be transformed in some way, perhaps to be more like this amazing leader and experience a better way of life and standards. This he achieves through constant dialogue and discussions with the people on a regular basis. In some respects, then, the followers are the product of the transformation. One of the methods the Transformational Leader uses to sustain motivation is in the use of ceremonial talks, discussions, renewal of cultural ties during festivals and trough development work in the communities. Through this and other dialoguing approaches, transformational leaders prove that they are people-oriented and believe that success comes first and last through deep and sustained commitment to the people by opening their doors of power to openness and transparency.

\section{Leadership, Vision, Power, Participation, Dignity and Conflict Resolution in Catholic Social Teachings}

From this brief survey of transformative and interactive leadership models and theories, the examination of the philosophical foundations of the human values of truth, peace, right conduct, non-violence and love as inherent divine values that make up man's personality, we can now identify that leadership in catholic theology and the social teachings is a concept that draws upon the transformational model; that leadership must be practiced to deliver services and solve the basic challenges facing the society that emanate from the values of vision, power, participation, dignity and conflict resolution. This window of understanding gives us the five recurring components to explore in Catholic Social Teachings. According to Mary Elsbernd (2004: p. 24) the dialectical linkage between these values and catholic social teachings are well placed and could be further elaborated upon as follows:

First with regard to vision, we expect to conclude that Catholic Social Teachings do identify some specific content to the vision, although the function of vision remains directional and inspirational. Second, we expect to determine that participation, especially in decisions which impact employees' lives, has long been supported in Catholic Social Teachings as an implication of human dignity. Third, we expect to discover that power has not been addressed at length in Catholic Social Teachings and hence an understanding of power as sharing resources and information is not a significant theme. Fourth, with regard to the affirmation of human dignity and worth, we expect to confirm its firm foundation in Catholic Social Teachings, especially Gaudium et Spes (1965). And finally we expect to find that since conflict is typically decried in Catholic Social Teachings, conflict resolution plays a minimal role in Catholic Social Teachings. Thus it seems that Catholic Social Teachings' statements on human dignity, vision, and participation may well provide a Christian and social ethical foundations to enhance the practice and theories of interactive leadership. In contrast, interactive leadership could well contribute the fruits of their practice and theory with regard to power and conflict resolution toward the continuing development of Catholic Social Teachings.

\section{The Role of Vision in Catholic Social Teachings and Transformational Leadership}

Vision plays a constitutive role in distinguishing transformational leadership from management (Brown, 1986; Tichy \& Devanna, 1986). Vision as it is used of a leader includes abili- 
ties such as: 1) imaging concrete results that could be defined and achieved by the enterprise in a future state; 2 ) sensitivity to the essence of the system or a systematic viewpoint; 3) creation of a collective viewpoint which satisfies individual wants and key values; and 4) communication so as to challenge and engender commitment to the project. This concept of vision has been critiqued as a one-way street, a detached clear seeing by the leader who then imparts the vision to the others (Belenky et al., 198X). Some interactive leadership theorists prefer the image of voice, understood as emphasizing both listening, communication, and dialogical interaction (Helgersen, 1990). In this metaphor, the vision is not created by the charismatic leader, but is rather listened into existence by the whole enterprise. In addition, there is a growing sense that "voice" must be connected to something larger than the immediate corporate future, i.e., that it is about justice (Rhodes, 1993) or a better world (Nygren \& Ukeritis, 1993) or at least a contribution to society. These latter two dimensions may have some connection to the use of vision in Catholic Social Teachings.

In contrast, Catholic Social Teachings use images from the Jewish and Christian scriptures to describe an eschatological vision, that is, a vision of the end of time, or the fulfillment of what was inaugurated in Jesus or in God's covenants with the human community. The metaphoric visions "reign of God", "the heavenly city Jerusalem," and "a new heavens and a new earth" are not understood as the utopias created by human longing but rather as a God-given Eschaton already begun and not yet fulfilled. Consequently the whole human community contributes to the articulation of the vision by listening for God's word in the unfolding events and crises of human history. As eschatological, the vision both describes "the way things ought to be”, and invites human persons to embody that vision already now in their attitudes, behaviors and choices.

The "heavenly city Jerusalem” (Gaudium et Spes, \#40.2 \& 43; Octagesimo Adveniens, \#37.1) is marked by peace, justice, community, freedom as well as healing, meaning, human rights and dignity, and "living exchange" between the divine and human. The "new heavens and the new earth" (Justice in the World, \#75; Laborem Exercens, \#27.4; Centesimus Annus, \#62.1) are recreated in justice, peace, love, dignity, community and freedom.

The contributions of Catholic Social Teachings undergird some of the shifts which interactive leadership is beginning in its reformulation of transformational leadership. These contributions include: 1) the vision is already given to the community or the enterprise and needs to be listened into articulation, but not created single-handedly by a charismatic leader; 2) the vision must be linked to flourishing of the whole human community, and not merely the enterprise; 3 ) the vision provides recurring values, namely, justice, peace, love, community, dignity and freedom, rather than strategies to ensure corporate survival into the future.

\section{Power in Catholic Social Teachings and Transformational Leadership}

Leo XIII gave his full thoughts and reflective energy to the discourse on political and public power and taught that the source of all power proceeded from God, who alone could give one person power over another (Immortale Dei, \#3; \#30; \#35). Power entailed the ability to enforce law, be it civil, natural, divine, or ecclesial law through which the people came to know and experience God. Leo rejected the concept of the people being the source of public power as a notion which lacked proof according to reason and therefore the power to insure public order (Immortale Dei, \#31). The source of political power in God did not prevent the people's participation in choosing the holders of political authority (Diuturnum, \#6; Pacem in Terris, \#52) who along with the laws represented God's power and consequently necessitated obedience (Pacem in Terris, \#50), unless they required what was contrary to eternal law (Sapientiae Christianae, \# 10).

A similar source of power was articulated by John XXIII as late as 1963 (Pacem in Terris, \#46) who grounded this understanding in Romans 13.1-6 and St. John Chrysostom's commentary on that passage. While John Paul II would probably agree that God is the source of all power, the encyclical Redemptor Hominis provided a more nuanced understanding, namely that society and people composing it are "master and sovereign of their own destiny"; John Paul II continues that such sovereignity remains unrealized if imposition of power by one group over other groups replaces the "exercise of power with the moral participation of the society or people” (\#17.5). The purpose of power is the promotion of the common good with particular attention to those who are unable to defend their legitimate interests (Pacem in Terris, \#56) and the protection of human rights (Ibid., \#60). In somewhat circuitous fashion and with the questionable attribution of rights to power, Redemptor Hominis, \#17.6 also links together the purpose of power, respect for human rights, and solicitude for the common good:

...The fundamental duty of power is solicitude for the common good of society; this is what gives power its fundamental rights. Precisely in the name of these premises of the objective ethical order, the rights of power can only be understood on the basis of respect for the objective and inviolable rights of man (sic). The common good that authority in the state serves is brought to full realization only when all of the citizens are sure of their rights.

Perhaps a similar purpose is reflected in the description of power as "getting things done so as to make a difference or to make others' lives better” (Canter \& Bernay, 1992).

Attention to the abuses of (economic) power probably is connected to the responsive or reactive nature of Catholic Social Teachings, that is, the encyclicals were written in response to major socio-economic events, the Industrial Revolution, the 1929 Depression, the globalization of the economy, the economic gap between so called developed and underdeveloped nations, etc. In the face of such events, the abuse of power is a likely theme. An understanding of power as domination or the ability to control and command remains a consistent description of power, although this definition is called into question by both feminist social ethicists and interactive leadership theories.

Catholic Social Teachings could well benefit from the contributions of both groups in its presentations of power. How much richer Catholic Social Teachings would be, if the foundational understanding of power was not domination of a limited resource, but sharing of information and resources which multiplies efficacy and agency. This is the emerging understanding of power in interactive leadership theories (Klenke, 1996; Rosener, 1990; Helgersen, 1990; Rost, 1991) as well as in feminist social ethics and other liberationist ethics.

The concept of power as agency is not completely absent in 
Catholic Social Teachings, although it is only used in the discussion of moral choices, i.e, moral power. In its discussion of socio-economic life, Gaudium et Spes laments the extremes of economic conditions which allows a few to enjoy "very great power of choice, (while) the majority are deprived of almost all possibility of acting on their own initiative and responsibility, and often subsist in living and working conditions unworthy of a human person” (\#63.2; Cf. Dives in Misericordia, \#11.1).

\section{The Role of Community Participation in Catholic Social Teachings and Transformational Leadership}

Rerum Novarum states: "all and each have a right to participate in the common good in a proportionate degree" (\#49). According to Leo XIII, all citizens without exception were required to make some contribution to the common good according to varying skills and gifts (\#35). He goes on to make particular mention of the contribution of unpropertied workers through their labor in the production of material goods; their contribution to the common good is so significant that the state ought to make sure that these workers participate in the benefits of the common good, at least through housing, clothing, a better life, and less hardship (\#36). This perspective is grounded in natural law, the natural propensity to associate with others, the Thomistic notions of contributive and distributive justice as well as the scriptural traditions (Ecclesiastes, 4: 9-10).

Rerum Novarum also speaks at length about self-governance in associations, although it is not clear whether the associations were groups of workers alone or mixed groups of employers and employees, or religious groupings. Such associations ought to choose freely how to manage their affairs and how to attain their goals (\#55). Mutuality in relationships ought to mark the distribution of tasks and offices so that discord is minimized (\#57). Some of the tasks noted included: spiritual goods of all workers (\#56); regulation of hours; health and safety safeguards (\#46); provision of jobs; relief in cases of accident, sickness, old age or distress (\#57); care for the poor; provision for the future (\#58); and a general opportunity for a better life (\#58.1). It is granted that these statements do not reflect participation in decision-making typically conveys in interactive leadership models of the 1990's; however it is worth noting that employees, either alone or with employers, were seen as capable of participating in decisions with what today would be termed benefits issues in the workplace.

These foundations of human dignity, responsibility to contribute and personal initiative are threaded through the following quotation from that document (\#91-93) on employee participation:

We, no less than our predecessors, are convinced that employees are justified in wishing to participate in the activity of the industrial concern for which they work. It is not, of course, possible to lay down hard and fast rules regarding the manner of such participation, for this must depend upon prevailing conditions, which vary from firm to firm and are frequently subject to rapid and substantial alteration. But we have no doubt as to the need for giving workers an active part in the business of the company for which they work - be it a private or a public one. Every effort must be made to ensure that the enterprise is indeed a true human community, concerned about the needs, the activities and the standing of each of its members. This demands that the relations between management and employees reflect understanding, appreciation and good will on both sides. It demands, too, that all parties co-operate actively and loyally in the common enterprise, not so much for what they can get out of it for themselves, but as discharging a duty and rendering a service to their fellow men (sic). All this implies that the workers have their say in, and make their own contribution to, the efficient running and development of the enterprise.

The United States Bishops’ Pastoral Letter, Economic Justice for All (1986) also address participation in the socio-economic arena. Their statements reflect some of the previous encyclical statements but weave them together in a new and integral way. Because human persons are socially constituted, life in society is a necessity and requirement for human existence, growth and fulfillment. This social anthropological foundation demands that persons actively and productively contribute to our social or common life; that is contributive justice requires persons to participate in the building up of the human community. Such a social anthropological understanding further demands that societies, according to distributive justice, provide what is necessary so that persons can participate in the building up of the human community (\#71). This includes the organization of economic institutions in such a way that persons can contribute to society in freedom and dignity (\#72).

\#77-78: Basic justice demands the establishment of minimum levels of participation in the life of the human community for all persons. The ultimate injustice is for a person or a group to be treated actively or abandoned passively as if they were nonmembers of the human race. To treat people this way is effectively to say that they simply do not count as human beings. This can take many forms, all of which can be described as varieties of marginalization, or exclusion from social life. ...Stated positively, justice demands that social institutions be ordered in a way that guarantees all persons the ability to participate actively in the economic, political, and cultural life of society. The level of participation may legitimately be greater for some persons than for others, but there is a basic level of access that must be made available for all. Such participation is an essential expression of the social nature of human beings and of their communitarian vocation.

Participation in the life of the community calls for the right to employment, for healthful working conditions, for wages and benefits sufficient to provide individuals and their families with a standard of living in keeping with human dignity, and for the possibility of property ownership (\#80). Economic participation can be enhanced through employment, widespread ownership of property, and increased participation by those entails real freedom a person currently excluded or marginated (\#91). The United States' Bishops insist that partnership and power to influence decisions about working conditions or even plant closings (\#302-303).

The brief survey of participation in Catholic Social Teachings can provide some solid foundations for what interactive leadership might practice under the vocabulary of "participatory decision-making”, "consensus-building”, "engendering commitment to the common task", "sharing responsibility", "supportive interactions", or "collaboration". These foundations include: first, the dignity of all persons which is the source of aspirations, rights, personal initiatives and abilities; second, an anthropological understanding of the human person as socially 
constituted; third, an understanding of justice as contributive, that is, requiring the contribution to the life of the whole human community; and fourth, an understanding of justice as distributive, that is, access to the benefits of the social enterprise which have accrued in part through the contribution of human work. In turn, the practice of participatory decision-making in the society could provide ecclesial leaders both with models and theory-laden practices from interactive leadership.

\section{The Role of Conflict Resolution in Catholic Social Teachings and Transformational Leadership}

When Catholic Social Teachings address conflict in the economic sphere, the context is typically a struggle between groups, be they unions, classes, or nations. On the contrary, the context of conflict resolution in interactive leadership models more typically appears as face to face, daily struggles within the work setting. This difference of context may actually provide a place for mutual influence between Catholic Social Teachings and interactive leadership. Yet conflict resolution in the economic arena is not a major theme in Catholic Social Teachings.

Both Rerum Novarum (\#40) and Quadragesimo Anno (\#94) looked to public authorities to intervene in conflictual situations in an effort to preserve social peace and common good. The social encyclical tradition demonstrates a clear preference for non-violent conflict resolution and an equally clear suspicion of revolutionary uprisings. Slow, deliberate, gradual growth from within is set forth as the law of nature with regard to the development process (Pacem in Terris, \#162). While admitting the ultimate necessity of strike, dialogue, negotiation, and discussion are held up as an ideal peaceful settlement of socio-economic disputes (Gaudium et Spes, \#68.2).

In contrast to these preferred ways, revolutionary tactics are seen as violent changes merely in the perpetrators of injustice (Quod Nunquam, \#7; Octagesimo Adveniens, \#45; Evangelii Nuntiandi, \#37), except in the case of "manifest, long-standing tyranny" which damaged personal rights and the common good (Populorum Progressio, \#30-31). In the encyclicals of John Paul II, this position is mitigated somewhat and struggle is recognized as normal and inevitable (Laborem Exercens, \#20.2; Centesimus Annus, \#14).

Scattered throughout the documents, however, are some principles guiding the resolution of conflicts. A first principle is the primacy of the person (Laborem Exercens, \#13.4), respect for their dignity (Centesimus Annus, \# 14.1 and 23.1), and their well-being (Gaudium et Spes, \#78.1). Secondly, the goal of the conflict must be justice (Gaudium et Spes, \#78.1; Laborem Exercens, \#20.2; Centesimus Annus, \#14) or the common good (Mater et Magistra, \#238; Centesimus Annus, \#23.1) or building up the community (Gaudium et Spes, \#85); the goal may not be the struggle itself or the elimination of the opponent (Laborem Exercens, \#20.2). Third, suggested strategies include negotiation, dialogue, witness to the truth (Centesimus Annus, \#23.1; Gaudium et Spes, \#68.2), "mutual assessment of arguments and feelings on both sides, a mature and objective investigation of the situation, and an equitable reconciliation of opposing views" (Pacem in Terris, \#93). Fourth, attitudes of respect and esteem must prevail (Mater et Magistra, \#238) And finally the documents call for ending injustices (Pacem in Terris, \#96; Populorum Progressio, \#30; Gaudium et Spes, \#83). The United States' Bishops in The Challenge of Peace (1983) specifically called for widespread training in conflict resolution by churches, education institutions and government agencies (\#223 \& 229).

The brief survey of conflict resolution in Catholic Social Teachings provides some principles for the practice of what interactive leadership describes as "the ability to negotiate", "honoring differences", "compromise” or "a conciliatory style under stress". Although conflict resolution is the subject matter of workshops, courses, and endless conversations in the workplace, current interactive leadership articles did not describe how conflict resolution skills are developed. Rather compromise and negotiation of differences were treated as inherent leadership assets. I would conclude that interactive leadership theory could benefit from an inclusion of these competencies and that Catholic Social Teachings would benefit from the reflective practice of conflict resolution by interactive leaders for whom negotiation, compromise, and conciliatory styles are daily honed skills.

\section{The Role of Human Dignity in Catholic Social Teachings and Transformational Leadership}

If we look at the beginnings of modern Catholic Social Teachings, we learn that human dignity is not a foundational concept. Rather Leo XIII saw a certain Christian dignity resulted from creation in the image of God, redemption in Christ Jesus, and final destiny with God (Rerum Novarum, \#24), which urged employers to reverence their workers as persons and not instruments for profit and production (\#17).

The influence of philosophical and theological personalism during the subsequent forty years established human dignity as a central concept in the encyclical writings of Puis XI. In Divini Redemptoris (1937), Pius sets forth a human anthropology built on the truths of nature and grace, namely that the human person was endowed from creation with an immortal soul as well as physical and mental gifts (\#27). The resultant dignity of the human person thus had its roots both in the natural order of creation and in the supernatural order of grace, final destiny and participation in the reign of God (Quadragesimo Anno, \#28). As a consequence of this human dignity, human persons had human rights (Ibid.; Laborem Exercens, \#4.1; Centesimus Annus, \#22; Gaudium et Spes, \#24).

John XXIII (1963) calls human dignity from nature and grace the fundamental principle for life together and the basis of human rights (Pacem in Terris, \#9-10):

...each individual man (sic) is truly a person. His is a nature, that is, endowed with intelligence and free will. As such, he has rights and duties, which together flow as a direct consequence from his nature. These rights and duties are universal and inviolable, and therefore altogether inalienable. When, furthermore, we consider man's (sic) personal dignity from the standpoint of divine revelation, inevitably our estimate of it is incomparably increased. Men (sic) have been ransomed by the blood of Jesus Christ. Grace has made them sons and friends of God, and heirs to eternal glory.

The above paragraphs serve as an introduction to John XXIII's listing of human rights; other passages from his encyclicals spelled out additional implications of human dignity: freedom and personal initiative (Pacem in Terris, \#34), equality (Ibid., \#44), participation in the business enterprise (Mater et Magistra, \#92), and the very structuring of economic systems 
(Ibid., \#83).

Vatican Council II devoted a complete chapter to "The Dignity of the Human Person” in its landmark document, Gaudium et Spes (The Constitution of the Church in the Modern World). Human dignity remains founded in creation and grace (\#12 and 19) and linked to human freedom (\#17). Gaudium et Spes’ original contribution, however, rests in its statements of the "practical and particularly urgent consequences” (\#27) of human dignity, namely:

- availability of everything necessary for a truly human life, including employment (\#26.1);

- obligation to help the least among us (\#27.1);

- work to end those things which oppose life, including "disgraceful working conditions, where men (sic) are treated as mere tools for profit” (\#27.2);

- tolerance (\#28);

- forgive injuries and love enemies (\#28.2);

- overcome discriminatory practices (\#29.1; Cf. Octagesimo Adveniens, \#13.2-16);

- establish human institutions to protect and promote human dignity (\#29.3).

The lengthy statement provides a high point in Catholic Social Teachings on human dignity. Subsequent documents reiterated the above points or addressed similar issues with other vocabulary. Paul VI prefers the terms "true humanism" or "full-bodied humanism" (Populorum Progressio, \#42-43) in part caused by his idealistic world view which believed that what was authentically human could be transformed into Christian virtue through intentional embrace by persons of good will.

John Paul II, in turn, emphasizes the dignity of the person in Christ (Redemptor Hominis, \#10-12.1), without denying dignity from creation in the image of God (Centesimus Annus, \#22). Many of the consequences and implications which previous Pontiffs associated with human dignity, John Paul II names demands of justice. For example, Centesimus Annus, \#34 notes that dignity demands that persons have the possibility to survive and to make an active contribution to the common good. Immediately preceding this sentence the same paragraph refers to the provision of basic human needs and skills training as a "strict duty of justice”. Perhaps one could say that for John Paul II the human dignity of persons requires just treatment.

Catholic Social Teachings treatment of human dignity provides some foundations for what transformational leadership might name "individual consideration", "enhance members" self-worth", or "concerned care in dealing with people”. These foundations include: personal giftedness from creation, redemption by Jesus, and indwelling presence of the Spirit. Catholic Social Teachings spell out some principles which ought to govern dealings with persons so gifted in human dignity. Of particular importance to management might be: equitable treatment, opportunities for participation, tolerance, ending discriminatory practices, promotion of human rights, the creation of structures which enhance dignity, and justice.

\section{Lessons for African Governance from the Catholic Social Teachings-Challenges of Transformational Leadership in Nigeria}

The Nigerian problem is one of injustice, corruption and lack of leadership. This is a transformational leadership challenge not a military or security problem. Nigerians and Nigeria need a revolutionary transformational leadership to drive the much needed transformation. Transactional leadership and recycling old political/power elite will not solve the problems and save Nigeria. To do this transformation requires that a new team with new mindset and integrity, new ideas and new ways of doing things be in place. The new team will true transformers passionate about service above self and sacrificing their selfinterests and comfort for Nigerians. They will role models. They will reject all official perks and privileges. They will travel by public transportation and live like the average Nigerian to experience what the average Nigerians does daily. They will be passionate about reducing the pain and suffering of Nigerians. They will improve the quality of life of the average Nigerian, inspire and uplift Nigerians especially the youth. They will tackle injustice, corruption and sycophancy frontally starting in the presidency and the former president. If the political/power elite and their sycophants see themselves as the real problem then there would be a paradigm shift and a new mindset leading to realistic solutions to Nigerian problems. Using 24 peace indicators, the new Global Peace Index Report listed Nigeria as one of the least peaceful countries (bottom five or 117 out of 121) in the world. It proved what some of us having saying that there are deadly different wars raging in Nigeria whether the power elite and some Nigerians realize it or not. Peace is not the absence of open conflict but the presence of truth, justice/fairness, freedom, equality, political stability, economic opportunity, health for all and other factors for the people's survival, safety, well-being and quality of life. The situation is that serious. Can the new government end these wars and make Nigeria peaceful?

Nigerians must make use of the concepts of transformational and interactive leadership to enthrone good governance in the country to bring about people participation and other attributes of good governance in the country. This new leadership model will help Nigeria and Nigerians to transform and develop the country. It only transformed leaders who can make a difference by helping the longsuffering Nigerians and solve the endless Nigerian problems. To do this they must appreciate that power comes from both God (Catholic social teachings) and the people (democratic ethos) and must be used in such a manner that people not only participate in decision making but the environment of exercise of power is such that their dignity, worth and intergrity and human rights are fully respected, promoted and provided for in all governance matters. Emeka Njoku (2012: p. 12) carries out the correct diagnosis of this transformative leadership challenge and how they can bring about change in the country:

At the paradigm level, the root cause is the leadership failures. Right transformational leadership team Transformation starts with the right transformation leadership team dealing with the root cause problems not the symptoms as well as positioning the country for greatness or world-class. Nigeria desperately needs the right transformational leadership team to drive the much needed transformation to save Nigerians, and Nigeria from continued unnecessary costly wars. Fairness/justice is also central to transformational leadership, transformation, peace and unity. These crucial pillars are missing in Nigeria. Get the right transformation team with new blood, new mindset and integrity and new ways of doing things instead of recycling old political/power cronies. 


\section{Conclusion}

In this paper we examined five key dimensions of the emerging interactive leadership theories for foundations or at least links with Catholic Social Teachings, namely vision, participation, human dignity, conflict resolution and power. With regard to vision, we found that Catholic Social Teachings identified specific content for vision and gave support to interactive leadership theories positions in which leaders listen to emerging visions (not create them) and visions that are linked to the whole human community (not only the corporate future). We found that the affirmation of others' dignity and worth has a firm foundation in creation and in the traditional doctrines of the Catholic Church and Sai concept of education inhuman values. From the article, it could be discerned that participation, especially in decisions which impact peoples' lives, has long been supported in Catholic Social Teachings as a fundamental human value that honors human dignity, worth and rights. It is less clear, however, that participation as used in transformative leadership theories in democratic setting conveys some of the other meanings uncovered in Catholic social teaching. In particular, we refer to participation's underpinnings in achieving all the dividends of development and democracy from the fulcrum of power which emanates, not from God, but from the people who are the electorates that voted and gave their mandate to those in authority. The contention of this article is not who gives power but how the use of power should be ethically moderated by the humane values as gleaned from the catholic social teachings. Actually, Nigeria's leadership crisis will need a paradigm shift drawn from the elements of transformative participation and other human values of respect for dignity, divinity and worth of the human person as being in creation meant to be happy and fulfilled.

\section{REFERENCES}

Achebe, C. (1993). The problem with Nigeria. Enugu: Fourth Dimension Publishers Ltd.

Achebe, C. (2012). Once there was a country. London: Heinman.

Albritton, R. L. (1998). A new paradigm of leader effectiveness for academic libraries: An empirical study of the Bass (1985) model of transformational leadership. In T. F. Mech, \& G. B. McCabe (Eds.), Leadership and academic librarians (pp. 66-82). Westport, CT: Greenwood.

Alimo-Metcalfe, B., \& Alban-Metcalfe, J. (2001). The development of a new Transformational Leadership Questionnaire. The Journal of Occupational \& Organizational Psychology, 74, 1-27. doi:10.1348/096317901167208

Antonakis, J., Avolio, B. J., \& Sivasubramaniam, N. (2003). Context and leadership: An examination of the nine-factor Full-Range Leadership Theory using the Multifactor Leadership Questionnaire. The Leadership Quarterly, 14, 261-295.

doi:10.1016/S1048-9843(03)00030-4

Avolio, B., Waldman, D., \& Yammarino, F. (1991). Leading in the 1990's: The four I's of transformational leadership. European Industrial Training, 15, 9-16.

Bass, B. (1985). Leadership and performance beyond expectations. New York: Free Press.

Bass \& Bass (2008). The Bass handbook of leadership: Theory, research, and managerial applications (4th ed.). New York: Free Press.

Bass, B. M. (1985). Leadership and performance. New York: Free Press.

Bass, B. M. (1998). Transformational leadership: Industrial, military, and educational impact. Mahwah, NJ: Erlbaum.

Bass, B. M., \& Avolio, B. J. (Eds.) (1994). Improving organizational effectiveness through transformational leadership. Thousand Oaks, CA: Sage Publications.
Belenky, Clinnnchy, Goldberger, \& Tarule (198X). Women's ways of knowing.

Brown, M. D. (1986). Leadership and organization transformation: A competency model. Unpublished Doctoral Dissertation, Fielding Institute.

Burns, J. M. (1978). Leadership. New York: Harper and Row.

Cantor, D. W., \& Bernay, T. (1992). Women in power. The secrets of leadership. Boston, New York \& London: Houghton Mifflin.

Fiedler, F. (1967). A theory of leadership effectiveness. New York: McGraw-Hill.

Haines, D. G. (1994). The power to lead. Forming women for public ministry. Journal of Supervision and Training, 15, 190-199.

Helgersen, S. (1990). The female advantage. Women's ways of leadership. New York: Doubleday.

Hinze, C. (1992). Power in christian ethics. Annual of the Society of Christian Ethics, 277-290.

House, R. J. (1977). A 1976 theory of charismatic leadership. In J. G. Hunt, \& L. L. Larson (Eds.), Leadership: The cutting edge. Carbondale, IL: Southern University Press.

House, R. J. (1971). A path-goal theory of leader effectiveness. Administrative Science Quarterly, 16, 321-338. doi:10.2307/2391905

Kotlyar, I., \& Karakowsky, L. (2006). Leading conflict? Linkages between leader behaviors and group conflict. Small Group Research, 37, 377-403. doi:10.1177/1046496406291388

Kotlyar, I., \& Karakowsky, L. (2007). Falling over ourselves to follow the leader. Journal of Leadership \& Organizational Studies, 14, 3849. doi:10.1177/1071791907304285

Kouzes, J., \& Posner, B. (1999). Encouraging the heart. San Francisco, CA: Jossey-Bass Inc., Publishers.

Klenke, K. (1996). Women and leadership. A contextual perspective. New York: Springer Publishing Company.

Knowledge-Sharing Kit, Canada Corps Knowledge Sharing Kit Guide to key concepts in governance and development 3.

Namus, B. (1992). Visionary leadership. San Francisco: Jossey-Bass.

Nissinen, V. (2006). Deep leadership. Finland: Talentum.

Njoku, E. A. (2012). Transformational leadership for Nigeria. London.

Nygren, D. \& Miriam, U. (1993). Religious leadership competencies. Review for Religious, 52, 390-417.

Pielstick, C. D. (1998). The transforming leader: A meta-ethnographic analysis. Community College Review, 26, 15-34. doi:10.1177/009155219802600302

Rhodes, L. (1993). Leadership from a feminist perspective. Word and World, 13, 13-18.

Roesner, J. (1990). Ways women lead. Harvard Business Review.

Rosener, J. B. (1990). The ways women lead. Harvard Business Review, 68, 119-125.

Rost, J. C. (1991). Leadership for the twenty-first century. New York, Westport, \& London: Praeger.

Sagaria, M. A. D. (1985). The managerial skills and experiences of men and women administrators: Similarities and differences. Journal of Educational Equity and Leadership, 5, 19-30.

Staham, A. (1987). The gender model revisited. Differences in the management styles of men and women. Sex Roles, 16, 409-429. doi:10.1007/BF00289552

Stryker, S. (1980). Symbolic interactionism: A social structural version. Menlo Park, CA: Benjamin/Cummings Publishing Company.

Tichy, N., \& Devanna, M. A. (1986). The transformation leader. New York: Wiley.

The 24 Peace Indicators, the New Global Peace Index Report (Nigeria/African Section).

Walsh, M., \& Davies, B. (Eds.) (1991). Proclaiming justice and peace. Papal documents from Rerum Novarum through Centesimus Annus. Mystic, CT: Twenty-Third Publications.

White, G. (1994). Civil society, democratization and development (I): Clearing the analytical ground. Democratization, 375-390. doi:10.1080/13510349408403399

World Bank (1995). World Bank participation sourcebook, environment department papers participation series. Washington DC: World Bank.

Yukl, G. (1999). An evaluation of conceptual weaknesses in transformational and charismatic leadership theories. Leadership Quarterly, 10, 285-305. doi:10.1016/S1048-9843(99)00013-2 